\title{
Research on Process of Listing and Working of IPO (Initial Public Offering)
}

\author{
Ajay Yadav, Sweta Goel
}

\begin{abstract}
Stock Market is the pioneer destination for any company to establish in Market. It gives a legal status for organizations and social recognition in market. Here, when a company decides to enter in market with the maximum attention or when a private firm decides to convert itself into a public sector firm, in that case IPO issuance is the best way to enter stock market.

Stock market provides a legal platform of trading with massive investors to give a kick start beginning of company. This article discuss about the process of IPO for Indian Stock Market listing. SEBI provides guidelines for the IPO of companies.
\end{abstract}

Index terms: IPO, Market, Process, Share Capital, Trading, Equity, Market Framework

\section{INTRODUCTION}

\subsection{What is IPO ( Initial Public Offering )}

An Initial Public Offering (IPO) is the process of offering share of the privately owned cooperation to public in a new listed stock. Unlisted company can list themselves on stock exchange by offering share capital in the primary market. Open offer issuance enables an organization to raise capital from open speculators.

Initial public offerings can be utilized: to raise new value capital for the organization worried; to monetize the speculations of private investors, for example, organization authors or private value investors; and to empower simple exchanging of existing property or future capital rising by ending up publicly exchanged.

An Initial Public Offering is a protections exchange where a company's offers are offered for public deal just because. This move changes the status of the organization from being a private firm to a publicly exchanged firm.

IPO or an Initial Public Offering is an amazing wellspring of pay to an organization that aides in its extension. The total procedure of recording and posting of an IPO is administered by principles and guidelines and it is significant for a financial specialist to know about the equivalent.

\subsection{Working of IPO}

An IPO is a major advance for an organization. It gives the organization access to collecting a great deal of cash. This gives the organization a more prominent capacity to develop and grow. The expanded straightforwardness and offer posting believability can likewise be a factor in helping it acquire better terms when looking for obtained assets too

At the point when an organization arrives at a phase in its development procedure where it trusts it is full grown enough for the rigors of SEC guidelines alongside the advantages and duties to public investors, it will start to publicize its enthusiasm for opening up to the world. Progressing from private to open status is a turning point in the life of any firm. For most firms and directors, the way toward leading an IPO is something they will just experience once. All things considered, there exists much vulnerability over the procedure, beginning with the choice of whether to open up to the world and including issues, for example, when to open up to the world, who to choose as counsels, how to value the offering and how to structure the administration of the recently open firm. A wide arrangement of scholarly writing has contemplated these issues, and the motivation behind this monograph is to audit the existing proof and furthermore to propose zones in which our comprehension is less finished and which would profit by further research.

Process of IPO

\section{Selection of Underwriter}

The very first step for listing IPO is to choose underwriter, to advise the company on its IPO for underwriting services.

- Underwriters present proposition and valuations talking about their administrations, the best kind of security to issue, offering value, measure of offers, and assessed time period for the market advertising.

- The firm picks its financiers and officially consents to underwriting terms through an underwriting understanding.

- Information regarding the company is compiled for required IPO documentation.

- Marketing materials are to be brought for pre-marketing of IPO.

- Process of auditable financial and accounting must be clear for every quarter.

- Company delivers its share capital on IPO specified date.

- The capital which is gotten as cash is reserved as stockholders equity on Balanced Sheet.

- Underwriters have a specified time frame to purchase an added amount of shares subsequent to IPO date.
Revised Version Manuscript Received on 10, September 2019. India

Ajay Yadav, Ph.D Scholar, ACCF, Amity University (U.P) Noida,

Dr. Sweta Goel, Asst. Professor, ACCF, Amity University (U.P)

Noida, India
Published By: Blue Eyes Intelligence Engineering \& Sciences Publication 


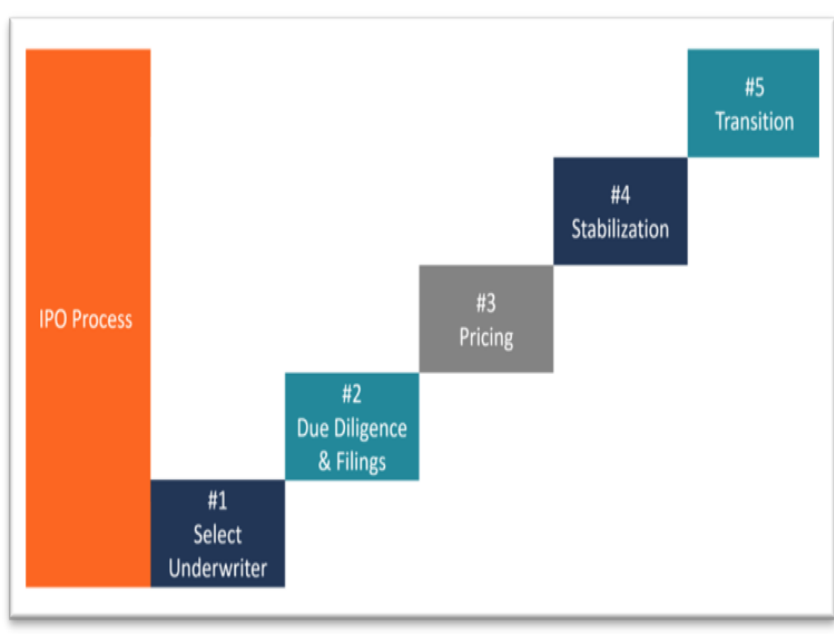

Figure 1.1 Process of IPO

\subsection{DOCUMENTS CONCERNED}

When the arrangement is settled upon, the speculation bank assembles an enlistment proclamation to be recorded with the SEBI. This archive contains data about the offering just as organization data, for example, budget reports, the board foundation, any lawful issues, where the cash is to be utilized and so forth. The SEBI at that point requires chilling period, in which they research and ensure all material data has been unveiled. When the SEBI favors the offering, a date (the compelling date) is set when the stock will be offered to people in general.

An underwriter must draft the following documents:

\section{Letter of Engagement includes}

Underwriting Discount: Gross spread is attained at by deducting the price at which the underwriter grasps the issue from the price at which they vend the same

Reimbursement clause: This provision commands that the issuing organization must cover the full scale of-the-pocket costs acquired by the guarantor, regardless of whether the IPO is pulled back during the due constancy arrange, the enlistment arrange, or the promoting stage.

\section{Red herring Document:}

In the cooling period, the underwriter makes an basic prospectus which comprises of the subtleties of the issuing organization, spare the powerful date and offer cost. When the red herring report has been made, the issuing organization and the guarantors showcase the offers to open speculators. Regularly, financiers go on street appears (called the pooch and horse appears - going on for 3 to about a month) to showcase the offers to institutional speculators and assess the interest for the offer

\subsection{Pricing}

After approval of IPO from SEC, the date gets decided. The day before the date, issuing company and underwriter decides the offer price. Deciding the price is important because it is the price at which company raises capital for company.

\section{Filing with SEBI}

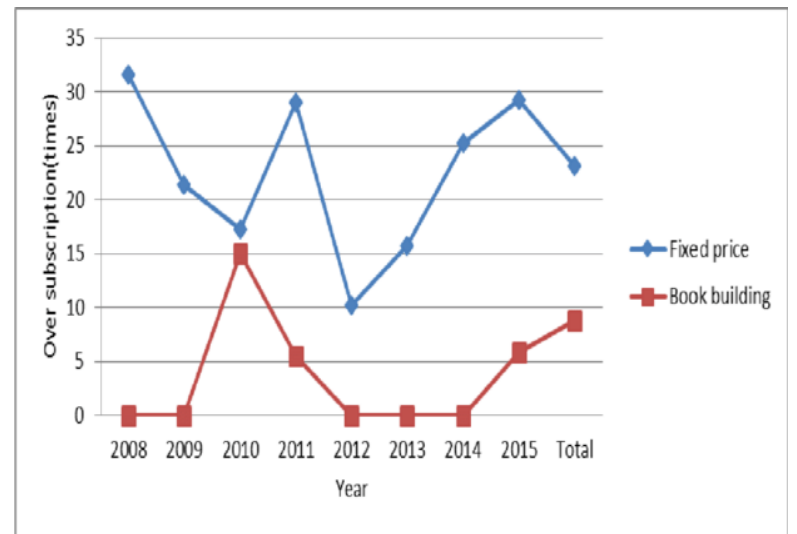

Figure 1.2 Graphical representation of pricing methods of IPOs

\subsection{Market Stabilization}

After the underwriter issuance, the underwriter has to provide recommendation. Adjustment exercises must be done for a brief timeframe - nonetheless, during this timeframe, the guarantor has the opportunity to exchange and impact the cost of the issue as disallowances against value control are suspended.

\subsection{Indian Experience with IPO Mechanism}

India has tried different things with a few IPO components. Beginning in September 1999, guarantors could pick between the fixed cost and book building strategies. Fixed value offers set the IPO costs preceding the offer date with no extension for correction. Offer assignments are proportionate to the amount offered. In book building techniques, the financiers designate shares, and the designations need not be relative. Throughout the years, there have been variations of book working in the Indian market. For example, in November 2005, the financiers' controls over IPO distributions were pulled back even in "book-fabricated" IPOs. In 2009, book building accompanied the choice of having "grapple" investors in the primary stage before the open offer. All the more as of late, a SME stage was acquainted for little firms wishing with do IPOs.

\subsection{Retail Investors}

An intriguing element of Indian IPO instruments is that retail and institutional parts have been reliably isolated. Numerous administrative worries in Indian IPOs originate from the retail financial specialist segment. The difficulties in this tranche are not due to IPO administrators, as guidelines give the financiers no tact in how retail offers are Apportioned.

There are two issues related with retail memberships. Investors may apply for IPOs

Furthermore, flip any designations that they get without putting in any capital all the while. Therefore, investors in IPOs could be people who might never take part in capital markets and for whom contributing is unseemly. To anticipate this wonder, retail investors are presently required to square assets through the Application Supported by Blocked Amount (ASBA). 
This progression is reasonable. It guarantees that solitary authentic members in the capital market can spot orders for IPOs. Gear through various offers is a subsequent test. While investors can't put various offers, there is proof that they do as such by exploiting feeble financial specialist distinguishing proof frameworks. For example, in the Yes Bank IPO, press reports recommend that there was distortion of financial specialist identity. The takeaway from this dialog is that while the maltreatment of optional allotment power is a key worry in the U.S., the worries in India have been extraordinary. In India, given the nonappearance of a hearty individual ID framework in the retail section, it is troublesome to guarantee that there are veritable investors who have the capital required to take an interest. With progressively hearty Know Your Customer (KYC) standards, these variations from the norm will maybe decrease, gave the KYC frameworks are not repetitive paper-filling practices but rather are powerful, control evidence frameworks.

\section{REVIEW OF LITERATURE}

Wolfgang Aussenegg, Pegaret Pichler, and Alex Stomper, (2006), considered IPO estimating in Germany to decide if when-issued exchanging gives data that is valuable to setting IPO offer costs, and regardless of whether such exchanging replaces Book building as a source of data. They found that when-issued exchanging uncovers significant data for evaluating IPOs, and that, when-issued exchanging has started, Book building isn't a wellspring of exorbitant data for estimating.

Specialists have inspected the impact that these substances have on IPO firm esteem. In an investigation of firms undertaking IPOs, Chang (2014) connected the notoriety of an association's vital union accomplices, supporting VCs, and the size of the association's system of vital collusions with the speed with which firms entered the open market. Echols and Tsai (2015) found that profoundly installed VCs take more firms to IPO that in this way beat the remainder of the financial exchange as contrasted and VCs with less estab-lished systems. Other work inspects the unexpected estimation of such support connections. For instance, Gulati and Higgins (2013) found that in hot IPO markets, financial specialists were bound to esteem connections to lofty guarantors (who by and large stay away from hazardous stocks). In virus damage kets, however, speculators were bound to esteem connections to lofty VCs (who may be particularly mindful). Regardless, we think minimal about explicit commitments these substances make in influencing IPO execution past the sign they send to financial specialists. For example, unmistakable partners can likewise give significant exhortation and advice, assets, and access to different partners, which can shape the executives choices, firm methodology, and execution results (Arthurs and Busenitz, 2008; Dimov and Shepherd, 2010; Pollock et al., 2014

O'Brian et al. (2015) affirm the reluctance of subsidiary experts to disseminate negative research reports so as to verify speculation banking commands and to limit potential clashes between the business and venture banking divisions and the administration of the customer firm. They moreover see that associated experts tend to distribute purchase suggestions sooner and all the more frequently than unaffiliated examiners after an organization has issued securities.

Arvind Chaturvedi, and Syamal K. Ghosh, (2012), broke down the causal factors behind high starting increases for Indian IPOs utilizing prior looks into also, testing them over an example of Indian IPOs to analyze the impact of non-principal factors and flagging consequences for under-valuing.

The writing on asset the executives proposes that financial specialists might be bound to react positively to the organizations' post-IPO item improvement endeavors to the degree that organizations can create novel and unforeseen blends (Morrow, Sirmon, Hitt, and Holcomb, 2017). Likewise, there is a need to ponder the degree to which IPOs empower vital flexibility or force in a company's post-IPO item improvement endeavors. Fruitful IPOs may give capital and authenticity that upgrade an association's alternatives with respect to making and utilizing asset blends (e.g., Miller, 2013). In any case, directors may likewise see that investors' sure reactions are a demonstration of positive support in existing item improvement endeavors, in this manner urging supervisors to keep up earlier strategies.

\section{METHODOLOGY}

Information for organizations issuing IPOs from March, 2000 to December, 2011, have been acquired from Prime Database, an association committed to the essential capital market covering reserve raising by the Indian corporate area and the Government through equity, obligation securitisation, in India or abroad. Data acquired from the Prime Database covers opening and shutting date of issue, value band, offer value, representatives share, date of posting, shutting cost toward the part of the arrangement, seventh day, multi month, 3 months, a half year, subtleties of the lead director/co-administrator, industry/segment, utilizes, and so forth. The subtleties of pay of the organization, business P/E proportion, date of endorsement of consolidation, and so on are taken from the draft plan recorded by every one of these issuing organizations with Securities and Exchange Board of India (SEBI), the advertise controller in India. In any case, since there are a ton of missing information in regard of the IPOs issued between April, 2015 to March, 2016 particularly as to the posting and shutting cost subtleties for various minutes, the reference time frame for this investigation that has along these lines been utilized is April, 2015 to December, 2016 subsequently covering 433 IPO issues.

IIP arrangement have been utilized to assess the pace of development of industry. The understood yield at cut-off cost for the 91 days Treasury Bills in the most recent seven day stretch of the month right away going before the month in which offers for IPOs have been shut is acquired from RBI month to month release as gave on the national bank site (www.rbi.org.in). The T-Bill yield has been utilized as 
intermediary for circumstance cost of capital. The Put-Call proportion of NIFTY list alternative as an intermediary for investors $^{e e}$ slant is sourced from National Stock Exchange (NSE).

In this examination, we gauge the transient introductory return for the example IPOs as the distinction between the main day shutting cost and offer cost. The normal short run starting return for all the 432 IPOs from April, 2015 to December, 2016 is 25.93 percent. The short-run starting return has descended essentially after some time as appeared in earlier inquire about As per Kumar (2015), this decrease is most likely because of the presentation of book-building process, an significant change that the open issue procedure has seen from the mid-nineties to the present day. As indicated by Pandey and Vaidyanathan (2012), the decrease in undervaluing could likewise be credited to a limited extent to the adjustment in guideline whereby the assignment to educated institutional financial specialists was permitted.

An examination of the pattern in starting return crosswise over present moment and medium-term time skyline (up to a half year time span) shows that the principal day introductory return which is exceptionally positive at about 25.93 percent for the main day winds up negative and is -1.22 percent for the half year time frame from the issue date, barring the main day return. The pattern is likewise in similarity with the worldwide discoveries that over the long haul and more data winds up accessible, dissimilarity of conclusion among idealistic and negative financial specialists will limit and therefore cost will drop in the market.

\section{IV.HYPOTHESIS}

The study looks at beginning and post-posting execution of IPOs. Therefore, the speculations being tried are:

(1) The IPOs are not undervalued dependent on the posting day execution.

(2) Financial specialists can't acquire irregular comes back from IPOs in the post-posting period execution.

\section{V.FINDINGS AND CONCLUSION}

An IPO can for the most part be finished inside 15 to 20 weeks. The careful timetable will fluctuate contingent upon market conditions, the extension and intricacy of the arrangement and a scope of different variables. As indicated by the optional research databases and with the end goal of this paper I have separated the entire procedure into private stage and open stage. Private stage manages those arrangement of procedures that manages the pre-readiness of the organization for issuing shares. This incorporates choosing a book running lead supervisor by the guarantor organization, doing every single legitimate commitment like reviewed budget summaries, gatherings, and so on. Then again, open stage manages those arrangement of procedures that manages the post-arrangement of the organization for issuing shares. This incorporates a declaration for the issue by the organization accommodation of a draft plan, doing roadshows, and so on.

An IPO is the opportunity to get a good beginning for a new coming company in market. It gives kick start to a newly listed firm in such a way that it gets maximum attention. IPO is the onetime process as it happens only once in a firm. There are numerous companies which jump into this sea of stock market through IPO way, as it draws market attention. Picking right time to offer IPO is very crucial while choosing a date for IPO. A major hit in the beginning is the foundation of renowned company.

\section{REFERENCES}

1. Bhushan Kumar Sinha (Corresponding author) Department of Economic Affairs, Ministry of Finance Government of India, New Delhi, India, Received: July21, 2013 Accepted: August 9, 2013

2. Dirk Baur, University of Western Australia Business School, Australia, Accepted: 17 December 2017 First Published: 12 January 2018

3. Dr. Nalina K B, 2Rakesh H M 1Assistant Professor, JSS CMS, Mysuru, 2Research Scholar, JSS CMS, Mysuru Corresponding Author: 1Dr. Nalina K B

4. Dr. Rajesh Kumar Agrawal The Institute Of Company Secretaries Of India (ICSI) - Centre For Corporate Governance, Research And Training (CCGRT)

5. IPO Mechanisms in India: A Brief Note Amit Bubna and N. R. Prabhala9

6. Ms. Vaishali Bakliwal Director Management Trainee ,The Institute Of Company Secretaries Of India (ICSI) - Centre For Corporate Governance, Research And Training (CCGRT) 